\title{
Enhancing The Reading Comprehension Of Students In Narrative Text Using Story Face Strategy
}

\author{
Albiansyah \\ Master of English Education Study Program, Syarif Hidayatullah State Islamic University of Jakarta \\ Email: albiansyah19@mhs.uinjkt.ac.id \\ Jhoni Saputra \\ Department of English Education, Islamic University of Indragiri \\ Joni.s4putra@gmail.com
}

\begin{abstract}
This study was a Classroom Action Research that deals with story face strategy's use to enhance the students' reading comprehension of narrative text. The purpose of this study was to reveal the execution of story face strategy in the process of narrative text teaching and learning, and also to describe about reading comprehension of after using story face strategy in classroom. The participants were all students of grade X.2 grade of Miftahul Huda Sungai Luar. The instruments to collect qualitative data were observation sheet, interview, and field note. The quantitative instrument is reading comprehension test. On the basis of data analysis, it is found that Story Face Strategy enhanced students 'understanding of reading in narrative text. The improvements occurred in cycle 1 and cycle 2 . The improvement of students' reading comprehension is 59.4 (enough) to 71.7 (good). The result suggests that the use of the story face strategy to enhance students 'understanding of reading in narrative text is successful for grade X.2 students. The variables that alter the enhancement of the students depending on the results of the interview and observation indicate students' enthusiasm when using of story face sheets in the story face strategy.
\end{abstract}

Keywords: story face strategy, reading comprehension, narrative text

\section{INTRODUCTION}

As a foreign communication tool, English is currently becoming a very popular language and it becomes more important in many fields, particularly in transferring science, technology, trades, politics, businesses, etc. It is used not only by native speakers but also by non-native speakers to communicate each other. It has been widely used as an international language in different areas of life. Therefore, learning English becomes necessity for most people worldwide to communicate and to get information around the world. One can hardly deny that English plays a very important role in the major aspects of life in this global era. It is the most widely spoken language in the world so that English today is fast becoming a lingua franca of international trade and commerce. With the challenges posed by globalization and technological advances, Information and Communication Technology (ICT) has become the most crucial one in gathering scientific information available on electronic media.

English is becoming an international language nowadays. In Indonesia, it is formally taught from primary school through to university. There are four English skills that the students will be taught, listening, speaking, reading, and writing. Reading is one of the four 
competencies that students need to have. But not only are they reading, the students will probably understand what they are reading. Based on Permendiknas (2006, 366), there are four kinds of texts that should be taught to the senior high school students, they are procedure, recount, descriptive and narrative. Since they are in the second grade of junior high school, narrative text is taught to the students and it will be taught until they are in the third grade of senior high school. So, learning how to interpret the narrative text well is really necessary for students in the 1 st grade of senior high school.

(Catherine Snow, 2002) defined comprehension as the process of simultaneously extracting and constructing meaning through interaction and involvement with written language. It consists of three elements: the reader, the text, and the activity or purpose for reading.

Furthermore, (Neufeld, 2005) stated that comprehension can be defined broadly as the process of constructing a supportable understanding of a text. comprehension is the ultimate goal of the reading process. They also defined Reading comprehension as constructing meaning by integrating the information provided by author with the readers' background knowledge. It requires that the reader interact with the text to construct meaning. So, the readers' background also influences their reading comprehension.

Comprehension of reading relates to ability of the readers in using meta-cognitive reading strategies for comprehending the meanings of the text. Besides, it is a complicated process that requires a combination of text and readers and three main styles of reading are usually reasonable are accuracy (phonological and orthographic processing included), fluency (including time), and understanding. (Klingner et al., 2007) defines understanding reading as the process of meaning building by coordinating a variety of dynamic processes that include word reading, comprehension of words and worlds, and fluency.

The implementation of reading comprehension to the students in language learning require the strategy to assist their understanding in English text likes graphic organizer which one of them is story face. (Cullen \& Metatla, 2019) story face is used in schools to facilitate the underplay of stories and narrative structure by children. It can encourage innovation as a team practice and foster community inter-action. (Sholichah, 2017) story face is a technique that helps students learn the elements of a book or story using a graphic organizer. Story face provides a graphical visual display for key narrative text content. A diagram (called a 'plot mapping') is used by this instruction method to visually represent the setting or the sequence of events and story character action.

In summary the main purpose of reading is comprehension. Reading comprehension of narrative text was one of genre that must be learned by the students in senior high school. The 
students had to know the structure and components in narrative text to make them easy comprehend the text. By constructing these items, the students could create understandable.

As stated by (Fajar, 2020) educational problems are lack of teacher creativity in developing learning styles, the teachers tend to only use the lecture method, without showing anything other. This results in students becoming bored and bored in capturing subject matter provided by the teacher. So that is what the teacher conveyed to students become less than optimal. The use of suitable strategy or technique in teaching and learning process is very necessary especially in teaching millennial students.

In addition, (Erti, 2020) he learning process in educational units is carried out in an interactive, inspirational, fun, challenging, motivating students to participate actively, and providing sufficient space for initiative, creativity, and independence according to talents, interests and physical development as well psychological learners.

The biggest challenge faced by students in the classroom especially in the narrative text learning process is that they do not grasp what the text tells them about. The key point of each paragraph is not known to them. The students would then conclude that the narrative text is uninteresting and difficult to understand. Because of this problem, the researchers want to find a solution to how, after reading it, the students can understand the narrative text.

Regarding on the study of MA students in the $1^{\text {st }}$ grade. Miftahul Huda Sungai Luar, when asked by the teacher, the students could not say the substance of the letter. In comparison, the students just got an average score of 60 and the KKM had 65. Consequently, they were unable to understand each narrative text they encountered, and it could impact their score in the reading section.

There were some factors, however, that caused this issue. Second, the instructor did not give the students different strategies to understand the narrative text. In addition, the students did not feel happy when they learned narrative text. They had just come across a really long text and they had to answer the questions after reading it. So, the researchers decided to use an enjoyable approach to enhance the reading understanding of narrative text by students.

Story face is one of the graphic organizers that was intended to assist students understand the text of the narrative. It is a story mapping change that improves reading and writing. The story face is an original adaptation of the common technique for story mapping that also uses a visual context for the narrative text to recognize, define, and remember elements (Staal, 2000). The instructor will ideally enhance the students' reading understanding of narrative text by using this graphic organizer. The narrative face provides a recognizable object to represent a story. Two circles reflecting the environment and character are the eyes. The nose is the issue, and the mouth consists of a series of circles that represent the key events leading to 
the resolution. By using the story face, the researchers thought it might enhance the understanding of reading by students.

The graphic and semantic organizers enable readers to graphically represent (write or draw) and arrange the ideas' meanings and relationships in the text (Armbruster et al., 2003). They come in a number of ways, including maps, graphs, charts, frames, pages, and clusters. The key benefit of these organizers for understanding tends to be their ability to strengthen the memory of the content of what they read by a reader. The story face not only offers a collection of shapes with names, according to (Staal, 2007), but also shows the overall images of a face that gives the reader a meaningful sense for comprehension. Based on these ideas, the researchers supposed that the graphic organizer of the story face could be used to enhance the reading understanding of narrative text by students.

The story face is an original adaptation of the common technique for story mapping that also uses a visual context for the narrative text to recognize, define, and remember elements (Staal, 2000). The story face offers a recognizable object on which to outline a story, instead of the complicated set of boxes with a mark in a typical story map. For incorporating specific details and secondary characters, the eyes are two circles reflecting the environment and the main character with eyelashes. The nose is the problem, and the mouth is made up of a series of circles reflecting the key incidents leading up to the resolution (Staal, 2000). Here is the example of story face :
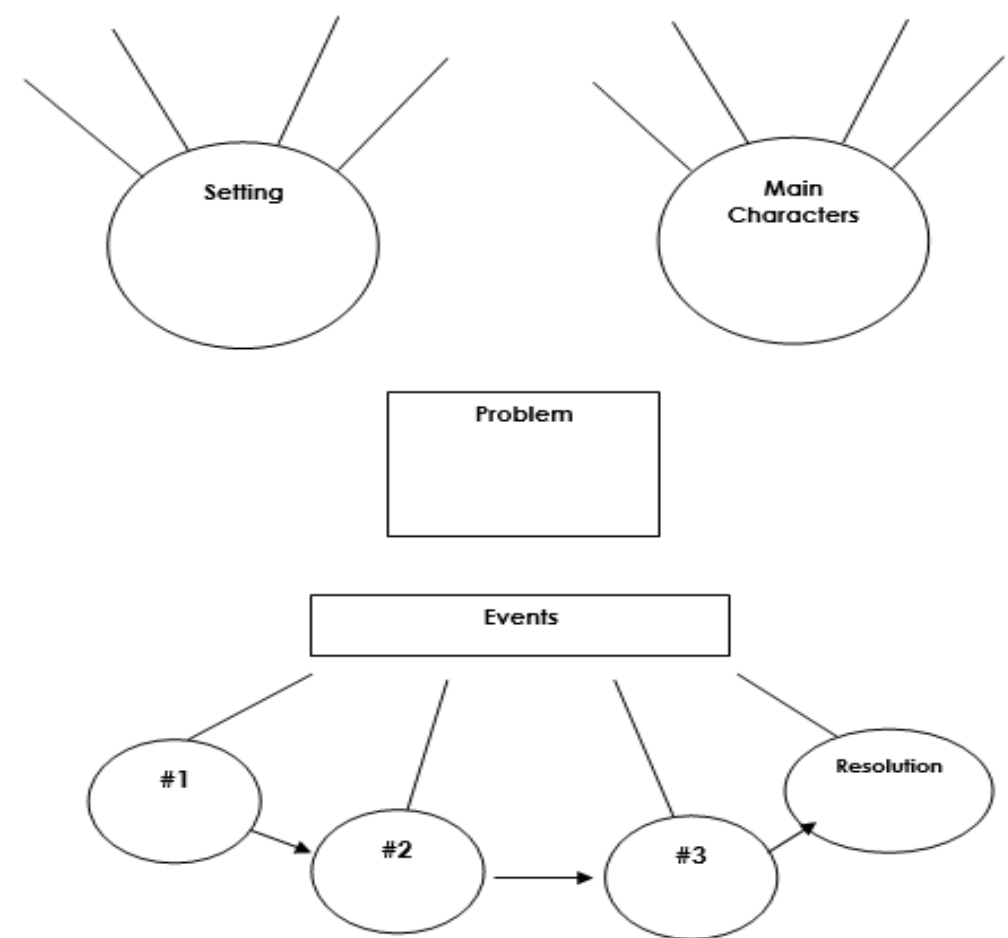

Figure 1. The Story Face Sheet of Happy Ending 
www.journal.univetbantara.ac.id/index.php/ijimm

(Capps, 2004) present the story as one of the organizational maps of Reading Techniques. The story face is a visual organizer that helps students interpret narrative texts. It acts as a story map that enables students to imagine the important elements of a narrative text, including setup, main characters, challenges, events, and resolution.

The story face is flexible to use, its flexibility is illustrated in the treatment of story resolution and in the number of story events. Some stories have happy ending, and some stories have sad ending, thus how the mouth of the story face is drawn (smiling or frowning) depends on the story resolution (Staal, 2000). The example of sad ending is below :
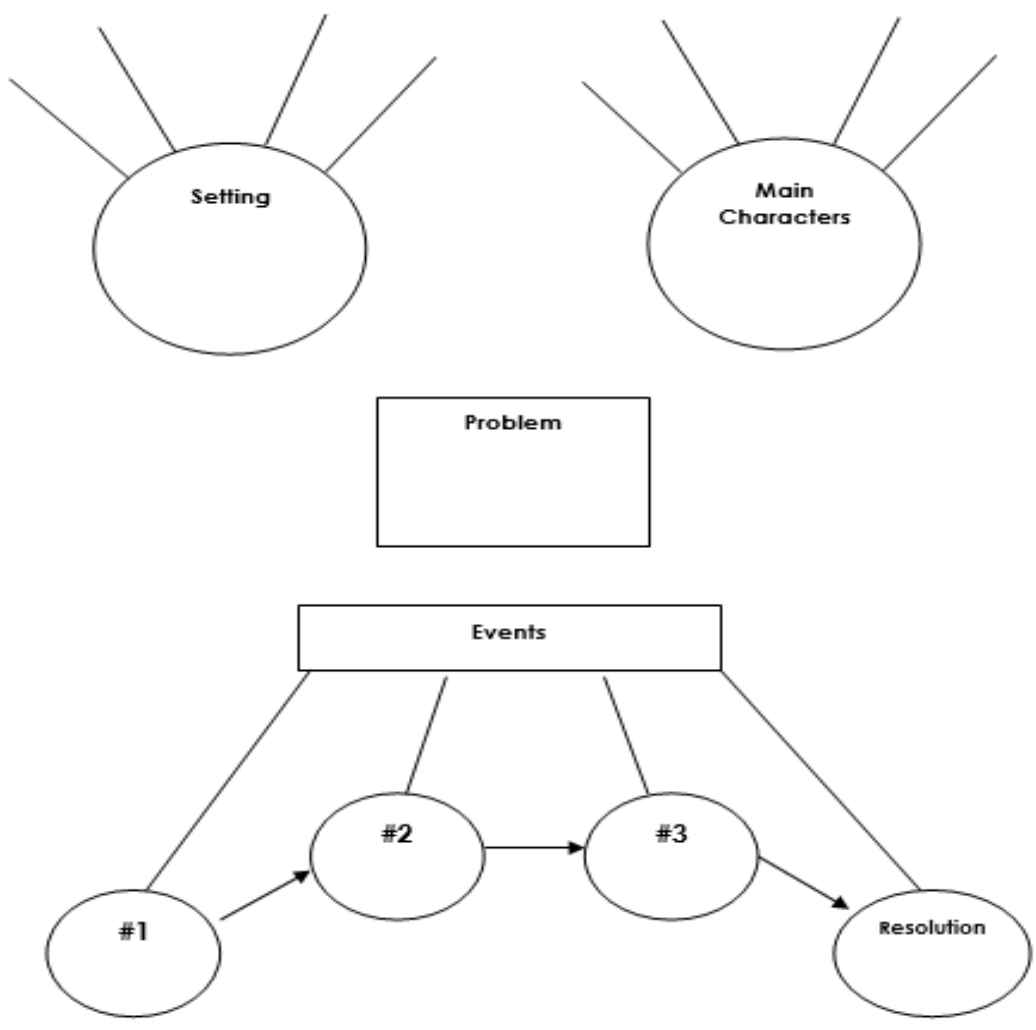

Figure 2. The Story Face Sheet of Sand Ending

In conclusion, the use of the story face may be an efficient way to enhance the understanding of students' reading. The story face model was designed to concentrate on the narrative text. By using the story face, the students were able to easily remember the narrative text aspect.

\section{METHODS}

Classroom action research is a method where participants systematically and carefully evaluate their own educational practice, using research techniques (Ferrance, 2000). Action research as a technique teachers may use to explore an issue or area of interest that is unique to 
www.journal.univetbantara.ac.id/index.php/ijimm

their professional background. It provides the foundation for a planned, systematic and recorded professional development process.

Depending on the participants involved, there are distinct kinds of action studies. A research plan may include a single teacher in his or her classroom researching a problem, a group of teachers working on a common problem, or a team of teachers and others concentrating on a large problem of a school or district. Individual teacher study typically focuses in the classroom on a single topic. The instructor can pursue solutions to classroom management issues, instructional strategies, use of materials, or learning for students. For a course they take, teachers may have help from their boss, principal, or an instructor.

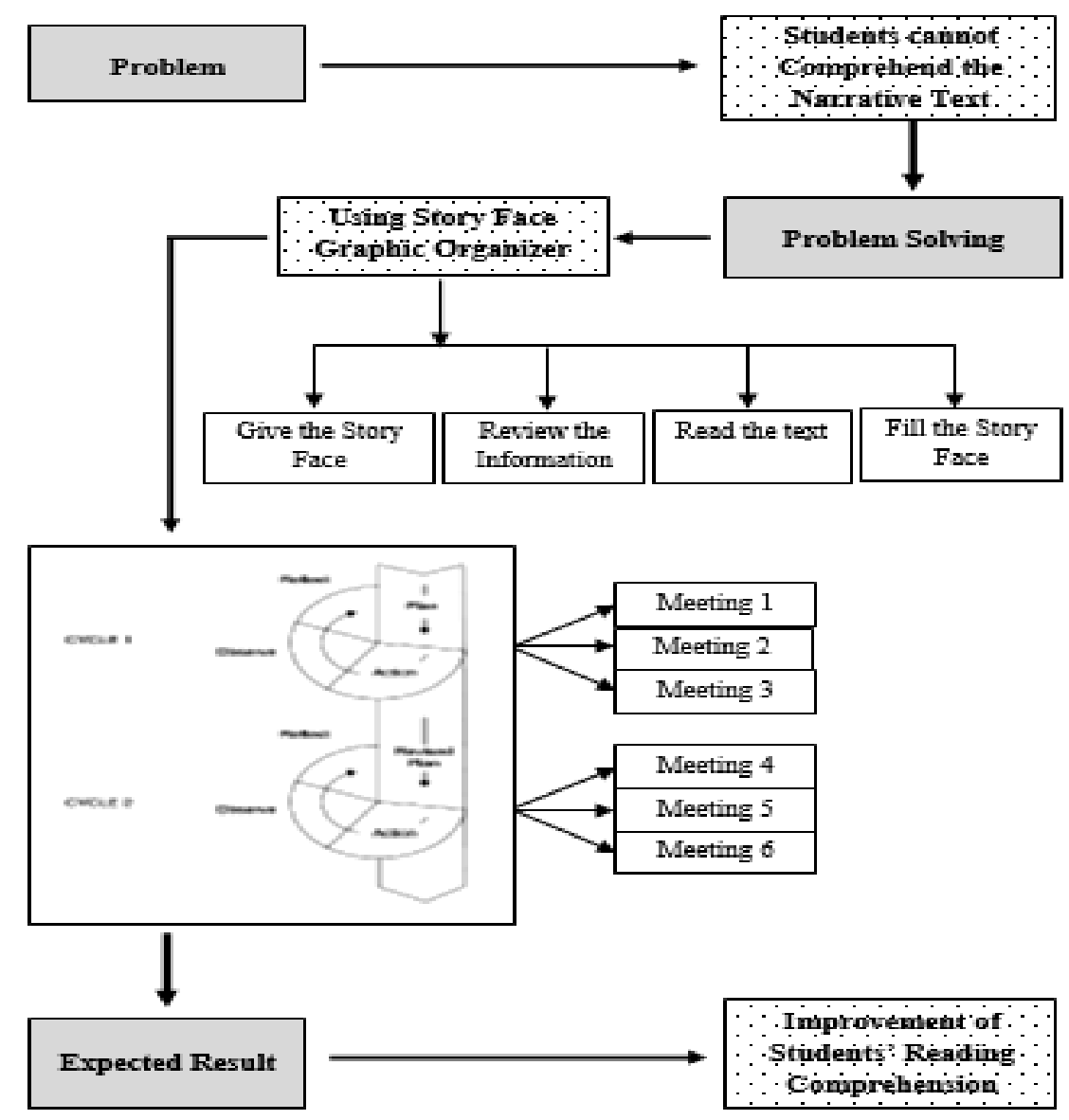

Figure 3. The Conceptual Framework of Research

From the framework, this research started from the problem about the students could not comprehend narrative text in MA Miftahul Huda Sungai Luar. To overcome the problem, the researchers used "Story Face" graphic organizer. In story face, hopefully the students could identify the characters, problem, setting, and resolution of the story. The step of using the story face were ; gave the story face to the students, reviewed the information that the students wanted to find, gave the text to the students, and the students filled the story face when they 
read the text. To apply the story face in the class, the researchers used classroom action research as research design. This research would be done in two cycles, in every cycle consist of three meetings, and every meeting consist of planning, action, observation, and reflection. The last, from this research hopefully the students' reading comprehension were improved.

In this research the students at class X.2 of MA Miftahul Huda were the participants. There were 26 students ( 9 males and 17 females). There were two types of data (qualitative and quantitative) that were collected in this research. Thus, two types of instrumentation would be created. The instruments for collecting the qualitative data were observation sheet, interview and fieldnote and for collecting the qualitative data was reading comprehension test. There were two kinds of observation sheets that would be used, they were observation sheet for teacher and observation sheet for students. These sheets would be used during the teaching and learning process in the classroom for every meeting and In interviewing the students, structured interview would be used. The interview would be conducted in every end of a cycle. The researchers and the collaborator will do the interview for collecting the additional qualitative data while Field notes would be used for keeping a record of actions of both teacher and students that were out of what mentioned in the lesson plan, for example, there were two students who did not pay attention to the teacher during presentation of how to use the story face. The technique of collecting the quantitative data was test on students' reading comprehension of narrative text by using reading comprehension test. The test would be given in multiple choices. It would be done in the last meeting of a cycle. In doing the test, the students would work individually. The collaborator would help the researchers in administering the test. All of these instruments were very needed to collect the data in order to help the researchersin answering the research questions. Since the classroom action research is a qualitative research that involves quantitative data to explain the improvement, the instruments help the researchersto see the connection between qualitative and quantitative data. Thus, the researchers were not just focus on qualitative data but also quantitative data. In relation to the instruments, the data from reading comprehension test was used to explain the improvement quantitatively. Then, the data from observation sheets, filed note, and interview are used to explain the factors that cause the improvement qualitatively.

\section{RESULT AND DISCUSSION}

The test was done at the third meeting in cycle I. There were 20 items of narrative text in multiple choices form. 


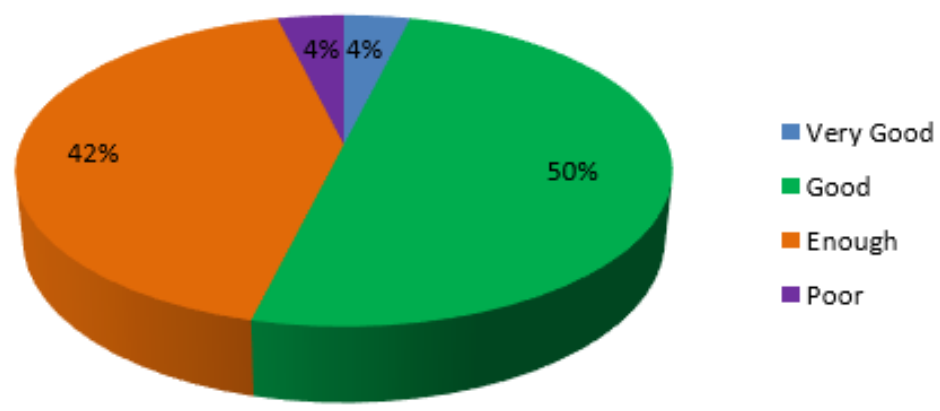

\section{Figure 4. The Percentage of the Students' Score in Cycle I}

The data of figure 4 described that one student or $4 \%$ who classified as having very good test of reading comprehension, $50 \%$ or thirteen students were good, $42 \%$ or eleven students were enough, $4 \%$ or one student was poor and there was no student classified on very poor level. The result shows students' reading comprehension test score was 59.42, this mean that students reading comprehension was categorized as enough.

In cycle II there were 2 meetings, at the fourth meeting the researchers also gave the story face sheets to the students, but the story was longer and here the researchers found that the students understanding of the text improved. In the fifth meeting, the students were asked to fill the story face. In this meeting the students could fill the story face alone. Most of them have understood how to fill the story face and they could comprehend the narrative text.

The test was done at the sixth meeting in cycle II. There were 20 items of narrative text in multiple choices form.

The Percentage of the Students' Score

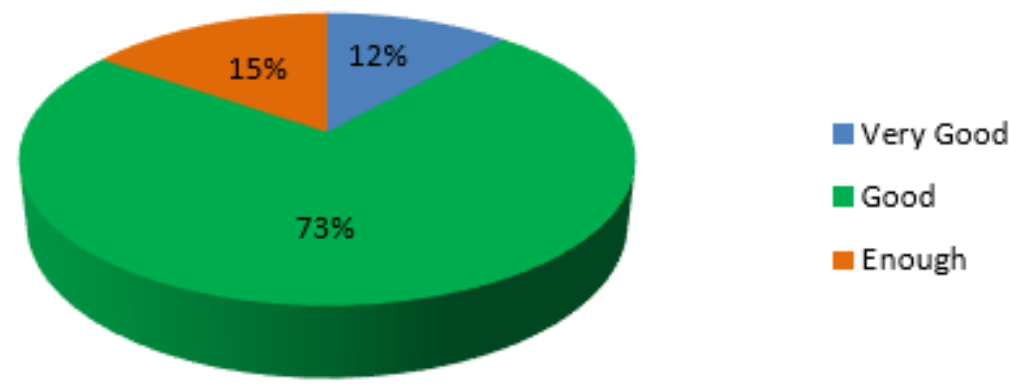

Figure 5. The Percentage of the Students' Score in Cycle II 
www.journal.univetbantara.ac.id/index.php/ijimm

The data of figure 5 described that three students or $12 \%$ who were classified as having very good test of reading comprehension, nineteen students or 73 were good, four students or $15 \%$ were enough, and there was no student classified on poor and very poor level. The result showed students' reading comprehension test score was 71.73 , this meant that students reading comprehension was categorized as good.

Therefore, the researchers did not continue the cycle because the students' reading comprehension were improved, the mean score of cycle II was higher than the mean score of cycle I. In addition, the mean score of cycle II reached The Criteria of Minimum Score (65). Here is the improvement of the students score in doing the reading comprehension test :

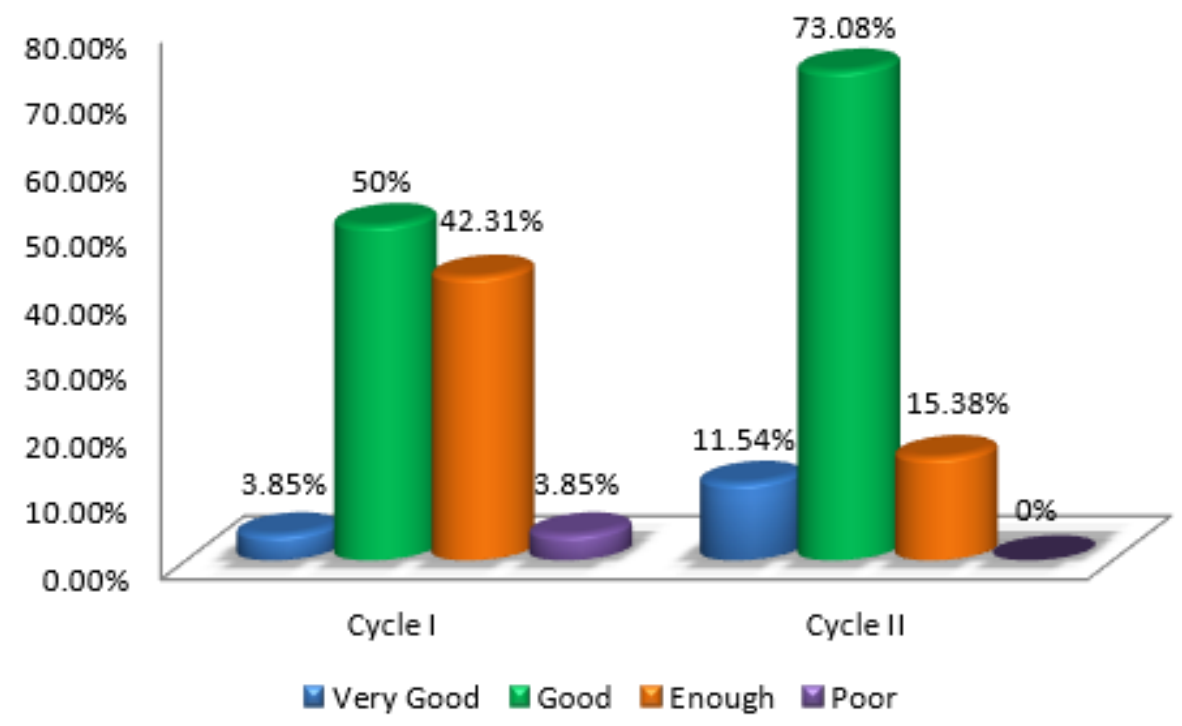

Figure 5. The Improvement of the Students' Score in Cycle I and Cycle II

This study has been carried out in two cycles. The researchers attempted to enhance students' interpretation of narrative text by using story face strategy. The students had thus strengthened their interpretation of narrative text from cycle to cycle.

Based on the data of the test in cycle I showed that the mean score was 59.42. This was categorized as Enough. While the mean score of the test in cycle II was 71.73. This was categorized as Good. This means that there was improvement on the students' reading comprehension of narrative text. It was from enough categorized into good categorized.

In addition, based on the data of observation showed that in the first cycle the students did not study in good condition, so the result of the test also did not reach the KKM. In the second cycle, the students studied in good condition. So, the students could reach the KKM.

Furthermore, from the interview showed that the students got motivation to learn about narrative text by using story face. The students also felt enjoy when they were studying about 
narrative by using story face. Additionally, the story face could help the students to remember what they had red because every cycle in story face showed the main points of narrative text. So, it helped the students to comprehend narrative text.

In conclusion, the data result of test showed that there was improvement on students' achievement in reading comprehension of narrative text from cycle I to cycle II. Then, based on data of observation and interview showed that the students felt enjoy and they could comprehend narrative text by using the story face graphic organizer.

\section{CONCLUSION}

It is concluded that story face strategy can improve students reading comprehension of narrative text. This can be seen from all the data obtained. Based on the data of the test, there is improvement of reading comprehension of cycle I to cycle II. It was from Enough category $(59,42)$ into Good category $(71,73)$.

While the factors that influence students' reading comprehension of narrative texts by using story face graphic organizer can be seen from the data of observation and interview. Based on the data of observation in cycle I showed that the students still not study seriously, some of them still do not pay attention to the teacher's explanation. Then, in cycle II showed that the student's study seriously. They do the task from the teacher very well. Besides that, the data result of interview with some students showed that the students got more understanding about reading comprehension of narrative text by using story face and they feel enjoy studying narrative by using it. Overall, the researchers concluded that the story face graphic organizer could increase the students' reading comprehension of narrative text in grade X.2 at MA Miftahul Huda Sungai Luar.

Finally, the researchers have some suggestions related to the data that have found in this research. Here are some suggestions from the researchers that the use of Story Face strategy is suggested to be used in teaching reading to improve students' reading comprehension and it make students feel enjoy to learn about narrative and other English teachers who do not use Story Face in teaching are suggested to apply it. Then, it is better for the teacher to find the interesting strategy in order to make the students want to learn about narrative. One of the strategies is by using story face graphic organizer beside that for the students who learn about narrative, it is better to use Story Face in order to get fun learning and get comprehension of narrative texts. Lastly, it is suggested to other researchers to investigate the use of Story Face in different level of education. 
www.journal.univetbantara.ac.id/index.php/ijimm

\section{REFERENCES}

Armbruster, B. B., Lehr, F., Osborn, J., \& Ed, M. (2003). Put Reading First: The Research Building Blocks of Reading Instruction Kindergarten through grade 3. In Educational Research.

Capps, L. \& B. B. S. (2004). ENHANCED SCOPE and SEQUENCE. Virginia Department of Education Richmond,.

Catherine Snow, C. (2002). Reading for Understanding. Science \& Technology Policy Institute.

Cullen, C., \& Metatla, O. (2019). Co-designing inclusive Multisensory story mapping with children with mixed visual abilities. Proceedings of the 18th ACM International Conference on Interaction Design and Children, IDC 2019. https://doi.org/10.1145/3311927.3323146

Erti, M. T., \& Pembelajaran, P. (2020). Peningkatan Kemampuan Guru dalam Melaksanakan Problem Based Learning melalui Supervisi Akademik di Sekolah Abstrak Improvement of Teacher 's Ability in Implementing Problem Based Learning through Academic Supervision in Schools Sesuai dengan Pasal 3 Unda. 2, 51-58.

Fajar, D. A. (2020). Penggunaan Media Visual dalam Pendidikan Jasmani dan Kesehatan. Indonesian Journal of Instructional Media and Model, 2(1), 1. https://doi.org/10.32585/ijimm.v2i1.627

Ferrance, E. (2000). Action research - Themes in education. In LAB, Northeast and Island Regional Education Laboratory at Brown University.

Klingner, J. K., Vaughn, S., \& Boardman, A. (2007). Teaching Reading Comprehension to Students with Learning Difficulties. What Works for Special-Needs Learners. Guilford Publications.

Neufeld, P. (2005). Comprehension Instruction in Content Area Classes. The Reading Teacher. https://doi.org/10.1598/rt.59.4.1

Sholichah, N. I. (2017), the Effect of Story Mapping on Reading Comprehension. INTAJ: Jurnal Penelitian Ilmiah, 1(1), 29-48. https://doi.org/10.35897/intaj.v1i1.43

Staal, L. A. (2000). The Story Face: An adaptatio of story mapping that incorporates visualization and discovery learning to enhance reading and writing. The Reading Teacher. 